\section{要 $-a-5$}

呼吸器疾患研究における実験研究の役割一生体肺 微小循噮観察法を用いた肺水腫の研究一

筑波大学臨床医学系 ${ }^{1}$, 筑波大学附属病院 ${ }^{2}$

$\bigcirc$ 蘇原泰則 ${ }^{1}$, 村山史雄 ${ }^{2}$, 森田理一郎 ${ }^{2}$, 船越尚哉 ${ }^{2}$ 塚田 博 ${ }^{2}$, 山本達生 ${ }^{2}$, 藤原 明 $^{2}$, 神山幸一 ${ }^{2}$,

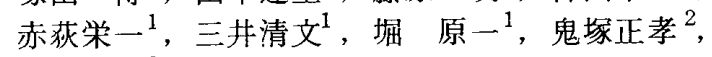
石川成美 ${ }^{2}$

目的：疾患の病因を解明する手段として種々の研究 万法が導入されるようになり, 染色体レベルや分子レ ベルでの研究もさかんである。しかし，我々毆床家に とっては, 生体にあるがままの状熊で藏器を観察し, 病変の発生や進行状況を視覚的に観察・追跡するほう がはるかに疾患の本質を理解し易く，また治療に結び つけ易い。このようなことから, 我々は生体顕微鏡に よる肺の観察法の開発を進めてきた。今回は, 各種肺 水腫における微小循環レベルでの病態を報告する。

研究対象：(1)術後の急性心不全や過剩輸液等に伴う 肺水腫の病態。(2)自然気胸による虚脱肺を再膨張させ た時に生ずる肺水腫の病態。

研究方法：Wistar 系ラットの肺を蛍光用生体顕微 鏡で観察し, 肺水腫の発生部位, 肺水腫の進展様式, 漏出血獎成分の大きさ等について検討を加えた。

結果：過剩輸蓷による肺水腫は肺練静脈から始まり， 漏出物はAlbumin より低分子のものであった。また急 性心不全による肺水腫ではAlbuminの漏出もみられた。 再膨張性肺水腫は肺細動脈, 肺毛細血管, 肺細静脈办ら 始まり，Albuminの漏出が顕著であった。

\section{要-a-7}

Hilar strippingによる呼吸機能の変化（特に，6 種不活性ガスを用いたVa/Q分布について)

久留米大学医学部第一外科

○葉倫建，杉山正治，永松佳囊，奥洋， 岩田定幸, 足達明, 西村寛, 掛川睡夫

目的：肺虎手術において根治性を得るためには肺門 部リンパ節郭清统かかせない，それに伴う迷走神経肺 枝の切断はやむお之ない。除神経肺の研究は数多くあ るが，6種不活性ガス老用いた $\mathrm{V}_{\mathrm{A}} / \mathrm{Q}$ 分布を測定した ものは少ないそここで，迷走神経肺枝沾よび䫓部迷走 神経を切断し，その前後で $\mathrm{V} a / \mathrm{Q}$ 分布老測定し㛟討し た.

方法：笑験 1 ) 雑種成犬在用いて左Hilar strippi ng群及び左単開胸群老作獘し，直後，2 4 日後， 7 日後、1 月月後にV。/Q分布を測定した。同時に，血 波力八，心拍出量，肺動眽圧已测定した。実験 2 ) 雑 種成犬でV。人分布，血液ガス，心拍出量，肺動脈圧 を測定し，次に，頸部で左迷走神経翰老切断した。切 断後7日目に同樣の測定を占こなった。

結果：実験 1 で统，術後4日目妾で统雨群共シャン

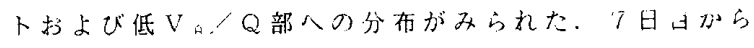
は, Hilar stripping群で高、部への分布がみら

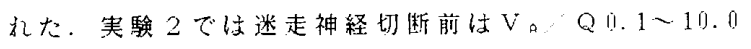
に1峰性の分布を示したが，切断後は新たに高、。 Q部への分布が見的れ，2峰性の分布を示した。これ は，死胫様效果として血液ガスにも若干の影響が睍ら れた。

\section{要 $-a-6$}

肺切除術中・術後管理に打ける prostaglandin $E_{1}$ の薬正効果

富山医科薬科大学第 1 外科

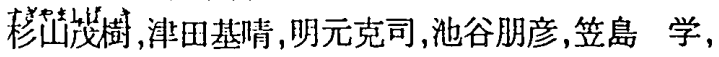
山本恵一

対象・方法：肺癌 等切除の16例に対し, 術前肺動脈 正，心拍出量测定時に,PGE ${ }_{1} 0.25 \mu \mathrm{g} / \mathrm{kg} / \mathrm{min}$ 的よ $0.05 \mu \mathrm{g} / \mathrm{kg} / \mathrm{min}$ を投与し，20分後に肺動脈圧, 体血 正，心拍出量を测定し，aminophylline 群と比較した。

絬果： PGE 1 投与-例 PGE 1 は血管平滑筋に作用 してI皿管昖张作用を有するとの報告があり，PGE ${ }_{1} 0.0$ $5 \mu \mathrm{g} / \mathrm{kg} / \mathrm{min}$ 投与例では体皿压の低下を認め,16例の 平均体血压は91.28 mmHg より78.71Hgへと低下し た。また,PGE ${ }_{1+1}$ 相仙管にも作用し, $0.05 \mu \mathrm{g} / \mathrm{kg} /$ min投与例で 16例中12例に脯動脈压の低下を認め, 平 均 $13.5 \mathrm{mmHg}$ より $12.38 \mathrm{mmHg}$ へと低下した。また， 全脯的管抵抗では, 平均245.7dyne $\cdot \mathrm{sec} \cdot \mathrm{cm}^{-5}$ より $188.13 \mathrm{dyne} \cdot \mathrm{sec} \cdot \mathrm{cm}^{-5}$ へと低下を示した。しかし $0.025 \mu \mathrm{g} / \mathrm{kg} / \mathrm{min}$ 投与例では心拍出量の増加は認め

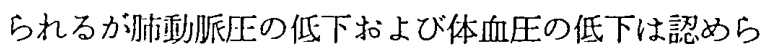
れなかった。aminophylline投与例との差基も検討した。

絬語： PGE, 投与样においては肺動脈圧を低下さ せるためには0.05 $\mu \mathrm{g} / \mathrm{kg} / \mathrm{min}$ 投与が必要であり， 全身折管抵抗の低下とともに心拍出量を增加させ、全 肺沿管抵抗の佂下をもたらすことが確認された。

\section{要 $-a-8$}

運動負荷による肺循環動態の検討

一肺機能諸量と関連して一

東北大学抗酸菌病研究所外科

○相良勇三, 久保裕司, 芦野有吾, 鈴木 聡, 千田雅之, 磯上勝彦, 那須元一, 斎藤秀行, 小野貞文, 佐久間 勉, 谷田達男, 小池加保児, 藤村重文, 仲田 祐

目的：肺切除術前ないし術後の患者の運動負荷によ る肺循環諸量の変化が肺機能諸量とどのように関連し ているかを検討した。

対象及び方法: 肺切除予定及び切除後の患者 15 名 (男11名, 女 4 名, 平均年令63土10歳)延へ18例を対象 上した。男 2 名, 女 1 名は術前術後の 2 回測定を行っ た。 FEV 1 は $1.84 \pm 0.40 \ell, \mathrm{FEV}_{1} / \mathrm{FVCは} 70.0 \pm 11.2 \%$, DLcoは $16.35 \pm 2.99 \mathrm{ml} / \mathrm{min} / \mathrm{mmHg}$ であった。これらの 症例に，仰臥位にてスワンガンッカテーテルを挿入， 平均肺動脈圧, 肺動脈きつ入圧, 心係数を測定し, 体 表面積当たりの全肺血管抵抗 $\left(\mathrm{TPVR} / \mathrm{M}^{2}\right)$ を求めた。 運動負荷は仰臥位のままエルゴメーターにて20ワット, 5 分間行った。

結果：FEV が $1.6 \ell$ 未満の症例では，運動負荷によ りTPVR $/ M^{2}$ は 6 例中 5 例で增加した。FEV が $1.6 \ell$ 以 上の12例では運動負荷により TPVR/M $\mathrm{M}^{2}$ が増加したのは 1 例のみで，他の11例は不変ないし減少した。DLcoを 16.35 $\mathrm{ml} / \mathrm{min} / \mathrm{mmHg}$ より大きい群 9 例と小さい群 9 例に分けると, 運動負荷によりTPVR/M²が增加したのは全例小さい群であった。 結論：運動負荷を行うと FEV 1 が少ない症例及びDLcoが 小さい症例ではTPVR/M ${ }^{2}$ が増加する傾向がみられた。 